which is listed at the end of the tables under the name of the territory from which it comes. Thus readers interested in one particular area, for example Kenya or Nigeria, can find on one page the number of foodstuffs analysed in that district, with the references to the original papers from which the material is derived. A separate table gives the figures for the salts and edible earths from Kenya, Northern Rhodesia, \&cc, where these have been analysed-an important contribution in view of the deficiencies generally noted in the mineral constituents of African diets. While this publication is intended chiefly for those medical or administrative officers with a special scientific training it should also be of use to missionaries, compoundmanagers and all those responsible for framing dietaries for large bodies of African scholars or workers, living under institutional conditions.

\title{
Theories of Native Education.
}

A NUMBer of important publications dealing with different aspects of native education have appeared within the last few months. From South Africa comes the report of an Interdepartmental Commission on the subject, appointed in July 1935. I In discussing the aim of education this commission declares that it must accept the realities of South African society-the industrial Colour Bar on the one hand, the impossibility of developing native life in isolation on the other. They do not hold, however, that the recognition of political barriers to African advancement precludes the attempt to raise the general educational level, and, rejecting the view of the Native Economic Commission that in native education there is much that is more important than the three R's, they postulate as necessary the provision of elementary education for every native child and of further instruction for those who can benefit from it. They stress particularly the very short school life of the average native child, and the need for working out a curriculum that will be more than a mere preparation for a further course that the vast majority will never undergo.

As though in answer to their demand comes the account by Dr. W. B. Mumford and Major Orde-Browne of their tour among the schools of French West Africa. ${ }^{2}$ Here is planning such as no other African colony can show-education devised so as to be at every stage complete in itself, and, if it is of the type that qualifies for a career, limited to the number for whom careers will be open. In the villages are bush schools, teaching largely oral French, agriculture, and hygiene; in the larger centres regional and higher primary schools which give elementary instruction in subjects closely related to native life, staffed with teachers trained at spots selected as typical of the

I Union of South Africa: Report of the Interdepartmental Committee on Native Education 1935-6 (U.G. 29, 1936). Pretoria: Government Printer. Pp. 157. 2s.

2 Africans learn to be French. London: Evans Bros. Pp. 174. 1937. 5 s. 
environment in which they will work. Then there are adult classes and craft schools which teach improvements in the technique and material of village industries. Thus a complete system exists centred in the life of the rural native. For the élite there are secondary schools, whence they can proceed to the Dakar Medical School or to further education in France; or they may take one of a series of technical courses; qualifying them as engineers, mechanics, clerks, veterinary assistants. Here, too, the language question receives a simple solution; only in adult classes is any language other than French allowed.

In the British colonies the improvement of village life tends to be a by product rather than the main aim of education. In East and Central Africa it is sought largely through a specialized agent-the Jeanes teacher, who, after spending a period of training in a model village, is sent out to disseminate the new standards he has acquired there. A conference of Jeanes organizers and teachers was held at Salisbury, Southern Rhodesia, in June I935 and its report appeared recently. ${ }^{\mathrm{I}}$ Representatives attended from all the territories which have adopted the system-Kenya, Nyasaland, and the Rhodesias-as well as from the Union. Each territory had some characteristic feature of its work to report. Kenya gives an elementary medical training to Health Demonstrators; Nyasaland holds special courses for Native Authorities; Southern Rhodesia has developed a system of parents' committees which encourage a genuine local interest in the work of the schools. While admitting that the Jeanes system had encountered difficulties, the Conference expressed a strong conviction of its value.

Yet another event in the history of African education is the appointment by the Secretary of State of a special commission to inquire into the possibilities of development of Makerere College, Uganda, and Gordon College, Khartoum, as institutions of advanced education for East Africa, taking into account the special needs of the territories concerned. This commission left London on January I, 1937. It includes an African member, Mr. Z. K. Matthews, who also holds an Institute Fellowship.

A brilliant analysis of the sociological implications of native education from the pen of Professor B. Malinowski ${ }^{2}$ was mentioned in the last number of this journal. It is appropriate to mention it again in this context, for it is doubtful if any of the educational policies which dispute the field in Africa to-day is based on a full understanding of the issues involved. Each in turn seeks to mould the African to its ends; rarely does any admit that the material is not infinitely plastic. If the inconsistencies of the 'dual mind', which

I Carnegie Corporation of New York. Village Education in Africa: Report of the Inter-Territorial 'Jeanes' Conference, Salisbury, S. Rhodesia, I935. Lovedale Press. Pp. viii +428. 2s. $6 d$.

2 'Native Education and Culture Contact', International Review of Missions, vol. $\mathrm{xxv}$, Oct. 1936 . 
gives the African new knowledge and new standards and denies him the opportunity to make them effective in practice, are absent from the French system, it may perhaps fall into the error of neglecting those educational agencies working through native institutions to which Professor Malinowski draws attention. And all alike could profit by consideration of the way to give through education 'the maximum preparation for contact with the white community'. (Communicated by Dr. L. P. Marr.)

\section{A Conference of South African Bantu Authors.}

Trurs Conference was convened by the Editor of the South African Outlook and was held in October, 1936, at Florida, Transvaal. It was the first meeting of its kind; the languages represented were Northern and Southern Sotho, Tswana, Xhosa, and Zulu. The Conference began its work by considering how the existing obstacles to the publication of manuscripts could be overcome. These obstacles are many, and the chief among them is that Africans have not yet fully developed a habit of buying or even of reading books, and that books intended for general reading command a small circulation, so that the difficulty of financing publication causes many a valuable manuscript to remain unpublished, not in South Africa alone. It was also intimated at the Conference that where publishers are willing to risk financial loss, African authors are often unwilling to part with their works without a lump sum payment. There was general agreement that a royalty on sales is the fairest form of recompense for authors. An informal survey undertaken at the Conference revealed a fairly extensive and varied amount of unpublished material in various languages. They comprised poems, folk-songs, and lays, plays, novels, short stories, folk-lore, histories, and biographies.

In view of the financial disabilities attending the publication of works in Bantu languages, attention was given to a plan to create an endowment fund to assist in the financing of Bantu publications, and steps were undertaken to approach several bodies for this purpose. An endowment fund for Bantu publications might become a real help in promoting vernacular literature. Production in African languages is still too young and too feeble to stand on its own feet; it needs assistance in order to grow strong, and this assistance must be financial. The manuscripts are there, the habit of reading and the number of buyers would increase if sufficient attractive books were available at moderate prices. If the South Africans succeed in collecting an endowment fund, it might set an encouraging example for other parts of Africa, where the need for help and encouragement is no less urgent.

The Conference expressed its appreciation of the competitions conducted for the direct encouragement of creative work by this Institute and by two South African Trusts. It was felt that the existing competitions are adequate and sufficient for the present. 